\title{
Väitösikkuna
}

\author{
Esa Juhani Konttinen ${ }^{a}$
}

\section{Huolellinen tutkimus argumentoinnista turvekiistoissa}

Yhteiskuntatieteiden maisteri Eerika Albrechtin tutkimuksessa turvesoiden käytön ja suojelun ajankohtaisia kysymyksiä lähestytään kahden ilmiökentän suunnasta, turpeennostoa koskevien paikallisten konfliktien tai paikallisten liikekiden ja toisaalta valtion harjoittamien politiikekakäytäntöjen näkökulmista. Kummallakin alueella on vahvat tutkimusperinteensä ja teoriakehitelmänsä.

Ympäristökonflikteja ja-liikekeitä koskevaa tutkimusta leimasivat 1970- ja 1980-luvuilla laajat kysymykset siitä, mitä nämä liikkeet ja konfliktit oikeastaan ovat ja miksi niitä ylipäätään syntynyt, nuo ilmiöthän olivat tuolloin joukkomittaisesti uusia ja siksi myös hämmentäviä. Tähän genreen kuuluu myös protestiliikesyklien tai liikeaaltojen tutkimus, joka on tunnistanut vahvempia ja heikompia ympäristöliikehdinnän kausia Suomessakin. Niiden rinnalle ja niitä tukemaan on kehkeytynyt useita eriytyneempiä konfliktien ja liikkeiden tutkimuksen suuntia. David Snow ja Robert Benford kehittivät 1980-luvulla kehysanalyysin hyödyntäen Erving Goffmanin klassista teosta Frame analysis. Kehysanalyysi tutkii, millaisia käsityksiä, oppeja tai "teorioita" liikkeiden piirissä kehitetään toiminnan tarpeellisuudesta. Toinen eriytynyt tutkimussuunta taas tutkii liikkeiden ja konfliktien organisoitumista: miten liikkeet rakentuvat ja verkostoituvat. Näin orientoitunut tutkimus voi myös kysyä, miten liike tai konflikti rakentuu osaksi laajempaa kansalaisyhteiskuntaa, siis miten liikkeet tyypillisesti organisoituvat ja toimivat juuri kyseisen yhteiskunnan kansalaisyhteiskunnassa. Sitten on esimerkiksi konfliktien hallittuun ratkaisuun tähtäävää eriytynyttä tutkimusta. Tähän linjaan voidaan lukea esimerkiksi sosiaalisen toimiluvan käsitteeseen nojautuva tutkimus. Siinä tarkastellaan hankkeen hyväksyntään ja epäämiseen liittyviä kysymyksiä hanketta edustavan yrityksen ja toiminnan vaikutuspiirissä olevien ihmisten ja yhteisöjen kanssakäymisen näkökulmasta.

Albrechtin valitsema tarkastelukulma edustaa vielä yhtä eriytynyttä ja teoreettisesti kehittynyttä tutkimuslinjaa liikkeiden erittelyssä. Hänen tutkimuksessaan näkökulmana on argumenttien käyttö konfliktitilanteissa. Miten ja minkälaisia argumentteja osapuolet ja toimijat kehittelevät edistääkseen tavoitteitaan. Millaiset argumentit ja kielenkäyttö on tehokasta? Miten konfliktitilanteet ja kulloisetkin yleisöt määrittelevät argumentaatiota? Tämän tutkimussuunnan taustana on laaja ja kehittynyt yhteiskuntatieteellinen suuntaus, joka tunnetaan yleisnimillä argumentaatioanalyysi, diskurssien tutkimus ja diskurssianalyysi. Se voi käyttää hyväkseen mainittuja tutkimuslinjoja, ja liittyy Albrechtin tutkimuksessa suoraan konfliktien hallintaan. Tutkimusta ohjaaviksi käsitteiksi nousevat Jürgen Habermasin ideaalisen puhetilanteen ja parhaimman argumentin käsitteistö sekä muiden argumentaatioanalyysin klassikoiden kuten Chaïm Perelmanin ja Lucie Olbrechts-Tytecan kehittämät teoriat, ja heidän jälkeinen tutkimus.

Toisen ilmiökentän, valtionhallinnon soidensuojelun politiikkakä̈ytännön analyysissä tukeudutaan niin ikään kriittiseen diskurssianalyysiin ja toimijuutta tarkastelevaan diskurssianalyysin variaatioon. Kriittinen diskurssitutkimus ymmärtää kielenkäytön ja argumentaation vallankäyttönä ja tutkii 
kielellistä vuorovaikutusta paljolti tästä lähtökohdasta käsin. Toimijat rakentavat argumentteja niiden arvioidun vaikutuksen näkökulmasta. Niitä yhdistetään virallisiin hallinnollisiin linjauksiin ja hegemonisiin diskursseihin. Sellaisista hyvin perillä olevat kompetentit toimijat ovat etulyöntiasemassa. Albrecht kohdentaa tarkastelun ajankohtaisiin kiista- ja kehittelykysymyksiin, joissa tutkittavien diskursiivisten ilmiöiden katsotaan esiintyvän ja vaikuttavan. Tutkimuksen tehtävänä on paljastaa diskurssien sisältöä ja dynamiikkaa.

Muutokset hallinnossa ovatkin olleet suuria. Perinteinen hierarkkinen hallinto johti konflikteihin rantojensuojeluohjelman toteutuksessa 1990-luvun taitteessa ja myöhemmin Natura 2000 -ohjelman suunnittelussa ja toteutuksessa. Seurasi tarve vuorovaikutuksellisten mallien kehittelyyn. Intressiosapuolten edustajat kutsutaan yhteiseen pöytään tutkimaan kulloistakin kysymystä ja etsimään ratkaisuja ja toimivia kompromisseja. Vuorovaikutteista hallintaa tukemaan yhteiskunta- ja politiikkatieteissä on kehitelty deliberatiivisen ballinnan ja deliberatiivisen demokratian käsitteistöä ja teoriaa. Hallinnon muutosta hallinnaksi edustaa myös uudenlainen kokeilukulttuuri, jossa kokeilujen avulla etsitään innovaatioita ja toimivia deliberaation muotoja.

Deliberatiiviset menettelyt ovat olennaisesti vuorovaikutteisia ja diskursiivisia. Diskurssianalyysillä on siis mahdollista tuottaa tietoa deliberatiivisesta hallinnasta, sen toiminnasta ja ongelmista. Tutkimusmenetelmällä on potentiaalia tuoda selvyyttä tämän päivän hallinnan ja poliittisen elämän keskeisiin ilmiöihin ja pulmiin.

Tutkimustyyppinä Albrecht ja (kahden osatutkimuksen osalta) hänen tutkijakumppaninsa Outi Ratamäki ja Maria Akerman soveltavat tapaustutkimuksen metodologiaa. Tutkittavana on kaksi pitkäkestoista paikallista turvekonfliktitapausta sekä soidensuojelun täydennysobjelman suunnittelutyöryhmän työskentely vuosina 2012-2015 asiakirjoineen. Kunkin tapauksen osalta on kerätty monipuolinen rikas aineisto. Tutkija hallitsee hyvin tapaustutkimuksen metodologian.

Albrechtin tutkimusasetelma sisältää paikallisen ja valtakunnallisen näkökulman, paikalliset ja valtakunnalliset intressit ja toimintamallit. Voidaan siis arvioida myös näiden kahden toimintakentän keskinäisiä suhteita: miten ne vaikuttavat (myös toisiinsa verrattuna) suopolitiikkaan. Ja taustalla on iso kysymys siitä, mitä deliberatiivinen hallinta merkitsee demokratian ja aidon poliittisen näkökulmista.

Tapausaineistoja analysoidaan diskurssi- ja argumentaatioanalyysin ohjaamana kvalitatiivisella sisällönanalyysillä. Tutkimusten vaiheista raportoidaan selkeästi ja riittävästi, mutta kirjallisuuden viittauskäytännössä on epätarkkuutta sikäli, että tutkija tyytyy usein viittaamaan koko lähteeseen, vaikka viittauksen kohde on selvästi jokin rajatumpi lähteen kohta. Tältä osin jää kaipaamaan suurempaa läpinäkyvyyttä. Ajankohtaiseen diskurssianalyyttiseen tutkimuskirjallisuuteen ja kriittiseen tieteelliseen keskusteluun deliberatiivisesta hallinnasta on perehdytty hyvin, ja sen kehittelyjä käytetään asiantuntevasti soidensuojelun täydennysohjelman valmistelutyöryhmän toiminnan erittelyssä. Tapaus on onnistunut valinta analyysiin. Paikallisten konfliktitapausten osalta jäi sen sijaan kaipaamaan niiden suhteuttamista turvekonfliktien koko kenttään. Kun yksi kolmesta tutkimuskysymyksestä muotoillaan lauseella "Mitkä ovat paikallisten turvekonfliktien ominaispiirteet Suomessa?", muodostuu ongelmaksi paljonko kaksi tapausta kertoo niistä. Nyt tuosta konfliktien alueesta annetaan niukalti tietoa tutkittavien tapausten ulkopuolelta. Ei silti ole epäselvää, etteivätkö tutkitut konfliktit ole merkittäviä. Diskurssi- ja hallintateorian näkökulmista ne soveltuvat hyvin tutkimukseen. Artikkeleissa ja yhteenvedossa tutkimusasetelmat, aineistot ja tulokset esitetään havainnollisilla taulukkoyhteenvedoilla.

Albrecht osoittaa, että viranomaissuunnittelu ja päätöksenteko turpeen nostoa koskevissa konfliktitapauksissa nojaa vahvasti luonnontieteellisiin suojeluarvoihin (purot, lammet, suojeltavat kasvi- ja eläinlajit ym.), kun taas ekosysteemipalveluilla (kuten soiden ja vesistöjen virkistyskäyttö) ei viranomaiskäsittelyssä juuri ole merkitystä, vaikka myös niitä koskevat kysymykset on nostettu esille soiden käyttöä koskevissa ohjeellisissa valtiollisissa asiakirjoissa. Silti pitkittyneet paikalliset kamppailut ja niissä myös asukkaiden käyttämät virkistyskäyttöargumentit ovat tutkijan mukaan vaikuttaneet suojeluun. Tuo vaikutus on luonteeltaan asukkaiden intresseihin perustuvaa poliittista.

Soidensuojelun täydennysohjelmatyöryhmän toiminta oli deliberatiivisen mallin mukaista konsensushakuista asiantuntijatoimintaa, jossa ekosysteemipalveluiden mukaisilla argumenteilla 
oli vähän sijaa. Sen työskentelyn aikana tapahtunut ministerivaihdos vaikutti työryhmän jäsenten argumentatiiviseen toimintaan. Osallistujat omaksuivat argumentteja toisiltaan ja käyttivät hyväkseen vallitsevia hegemonisia diskursseja, kuten kestävän kehityksen diskurssia.

Albrecht päätyy samankaltaiseen lopputulemaan kuin monet (muut) kriitikot. Hän ottaa varovaisesti kantaa suureen kysymykseen deliberatiivisen hallinnan luonteesta. Vaikka deliberatiivinen hallinta on lisännyt osallisuutta ja hallinnon proseduriaalista legitimiteettiä, on se kriitikoiden mukaan samalla kaventanut demokratian mukaista legitimiteettiä. On väitetty, että niiden mukana poliittiset kysymykset siirtyvät laajasta julkisuudesta managerien ja eksperttien toiminnaksi. Samalla kysymysten luonne poliittisina valintakysymyksinä hämärtyy ja markkinaperustaiset toimintamallit saavat jalansijaa. Uudenlaisen hallinnan myötä olemme kriitikoiden mukaan siirtymässä post-poliittiseen ja post-demokraattiseen tilaan, jossa aidolla poliittisella on aiempaa vähemmän tilaa ja valinnat ovat siirtymässä tosiasiallisesti pois kansan ulottuvilta. Konsensushakuinen asiantuntijatyöskentely uhkaa etäännyttää kansalaisia todellisista poliittista valinnoista. Tarvitaan siis elementtejä jotka vahvistavat aitoa poliittista. Ympäristöliikkeenkin on syytä varoa tempautumista liiaksi deliberatiivisten toimintamallien pauloihin. Varsinaisesti uusia avauksia tai toimenpide-ehdotuksia sen suhteen, miten demokratiaa ja poliittista voitaisiin vahvistaa suopolitiikassa, Albrecht ei tee.

Kokonaisuutena Albrechtin tutkimus osoittaa vahvaa yhteiskuntatieteellistä tutkimusosaamista ja hyvää oppineisuutta tutkimuksen teoria-alueilla. Se tuo hyvin työstettyä tutkimustietoa ajankohtaisista ympäristöpoliittisista kysymyksistä. Turvekonflikteista työ on ensimmäinen väitöskirjatasolla. Eerika Albrechtin tutkimus kohdistuu ympäristöpolitiikan ydinalueelle. 